\title{
Ocena wpływu kluczowych czynników na emisję GHG w cyklu życia biometanu
}

\section{Assessment of the key factors affecting GHG emissions in the life cycle of biomethane}

\author{
Kamil Berdechowski \\ Instytut Nafty i Gazu - Państwowy Instytut Badawczy
}

\begin{abstract}
STRESZCZENIE: Jednym ze współczesnych problemów społeczeństw rozwiniętych jest generowanie coraz większej ilości odpadów. Odpady te pochodzącą zarówno z gospodarstw domowych, jak też z rolnictwa oraz z różnych gałęzi przemysłu. Znaczną część spośród ogółu odpadów stanowią odpady pochodzenia biologicznego, nadające się do powtórnego wykorzystania. Jednym ze sposobów na zagospodarowanie odpadów o takim statusie może być ich wykorzystanie w procesach fermentacji metanowej, w wyniku której powstaje gaz o wysokiej zawartości metanu. W rezultacie oczyszczenia biogazu otrzymuje się biometan, który może mieć zastosowanie jako surowiec do produkcji energii elektrycznej, ciepła, ale także może być wykorzystany jako paliwo transportowe. W przypadku zastosowania w transporcie i ze względu na biologiczne pochodzenie surowca otwiera to możliwość zaliczenia metanu z biogazu na poczet realizacji Narodowych Celów Wskaźnikowych. Konieczne jest w tym celu spełnienie szeregu wymagań. Poza wymaganiami jakościowymi, które dotyczą finalnego produktu, należy spełnić wymagania w zakresie zrównoważonej produkcji biopaliw. Te z kolei mają związek ze wszystkimi etapami cyklu życia biopaliwa. Szereg tych wymagań dotyczy pochodzenia surowców, z których otrzymano biopaliwo, oraz wymogów w zakresie minimalnego progu ograniczenia emisji gazów cieplarnianych liczonej w cyklu życia. W ramach niniejszej pracy przeanalizowano proces produkcji biometanu pod kątem emisji gazów cieplarnianych (GHG), uwzględniając wszystkie etapy, począwszy od uprawy / zbiórki surowców aż po wytworzenie gotowego produktu (biopaliwa CNG). Dla porównania przyjęto dwa modele, tj. wykorzystanie w biogazowni surowca odpadowego (obornik) i zastosowanie surowca pełnowartościowego (kukurydza). Stosując się do metodyki obliczeń podanej w dyrektywie 2009/28/WE, obliczono poziomy ograniczenia emisji gazów cieplarnianych dla obu surowców. Dodatkowo dla każdego z surowców przeprowadzono dwuwariantową kalkulację zakładającą różne sposoby postępowania z pofermentem. Na podstawie uzyskanych wyników zidentyfikowano kluczowe czynniki mające wpływ na poziom emisyjności procesu produkcji biometanu.
\end{abstract}

Słowa kluczowe: biogaz, biometan, biopaliwo, emisja gazów cieplarnianych, ograniczenie emisji GHG.

ABSTRACT: One of the contemporary problems of developed societies is the generation of more and more waste. This waste comes from households but also from agriculture and from various industries. A significant part of the total waste is biological waste, which can be reused. One way to manage waste with this status can be to use it in methane fermentation processes that produces high methane gas. As a result of biogas purification, biomethane is obtained, which can be used as a raw material for the production of electricity and heat, but it also can be used as transport fuel. In the case of use in transport and due to the biological origin of the raw material, this opens the possibility of including methane from biogas in the implementation of National Indicative Targets. To this end, it is necessary to meet a number of requirements. In addition to the quality requirements that apply to the final product, the requirements for sustainable biofuel production should be met. These, in turn, apply to all stages of the biofuel life cycle. A large proportion of these requirements relates to the origin of the raw materials from which the biofuel was obtained and the life cycle requirements for the minimum threshold for reducing greenhouse gas emissions. As part of this study, the biomethane production process was analyzed for GHG emissions, taking into account all stages, from growing/collecting raw materials to producing the finished product (CNG biofuels). For comparison, two models were adopted, i.e. the use of waste raw material (slurry) in a biogas plant or the use of wholesome raw material (maize). By applying the calculation methodology given in Directive 2009/28/EC, the levels of greenhouse gas emission savings for both raw materials were calculated. In addition, a bi-variant calculation was carried out for each raw material, assuming different digestate storage methods. Based on the results obtained, key factors affecting the level of emissivity of the biomethane production process were identified.

Key words: biogas, biomethane, biofuel, GHG emission, GHG emission savings.

Autor do korespondencji: K. Berdechowski, e-mail: kamil.berdechowski@inig.pl

Artykuł nadesłano do Redakcji: 17.12.2019 r. Zatwierdzono do druku: 28.08 .2020 r. 


\section{Wprowadzenie}

W ostatnich latach nastapił znaczny wzrost zainteresowania produkcją biogazu. Wynika to z rosnącego zapotrzebowania na paliwa pochodzące z surowców odnawialnych. Kolejny powód zainteresowania biogazowniami wynika $\mathrm{z}$ faktu, że pozwalają one w doskonały sposób zagospodarować odpady i pozostałości z rolnictwa, gospodarstw domowych, pozostałości z przetwórstwa itp. Zainteresowanie ww. tematyką jest widoczne także w środowiskach naukowych. Tematyka produkcji biogazu oraz - w następstwie - biometanu jest poruszana w wielu publikacjach naukowych. Analizowany jest potencjał biogazu rolniczego, możliwości jego zastosowania, w tym także w transporcie, rodzaj surowców wykorzystywanych do jego produkcji, a także analizowany jest jego skład ilościowy i jakościowy (Szparkowska, 2004; Horschig et al., 2016; Pulka, 2019). Z faktem, że biogaz i otrzymywany z niego biometan mogą być wykorzystywane jako biopaliwo, wiąże się konieczność spełnienia wymagań odnoszących się do ograniczenia emisji GHG liczonej w cyklu życia oraz wymagań dotyczących pochodzenia surowców do jego produkcji. Dlatego wiele prac badawczych poświęconych biometanowi zawiera elementy analizy cyklu życia tego paliwa (Adelt et al., 2011; Buratti et al., 2013; Szabó et al., 2014; Tonini et al., 2016; Czyrnek-Delêtre et al., 2017; Ardolino, 2018; Koido et al., 2018; Adams i McManus, 2019; Esteves et al., 2019). W Polsce biogaz może stanowić znaczące źródło energii, którą można zaliczyć na poczet realizacji Narodowego Celu Wskaźnikowego. Konieczne jest jednak do tego spełnienie szeregu wymagań. Oprócz kwestii jakościowych jednym z obowiązków wytwórców biometanu na cele transportowe (podobnie jak wszystkich biopaliw zaliczanych do NCW) jest uzyskanie certyfikatu potwierdzającego spełnienie kryteriów zrównoważonego rozwoju.

Narodowy Cel Wskaźnikowy (NCW) zgodnie z Ustawą z dnia 25 sierpnia 2006 r. o biokomponentach i biopaliwach ciekłych (Dz.U. z 2006 r. nr 169, poz. 1199) jest definiowany jako minimalny udział biokomponentów i innych paliw odnawialnych zużytych we wszystkich rodzajach transportu w ogólnej ilości paliw ciekłych i biopaliw ciekłych zużywanych w ciągu roku kalendarzowego w transporcie drogowym i kolejowym, liczony według wartości opałowej. Do realizacji NCW zobowiązani są przedsiębiorcy wykonujący działalność gospodarczą w zakresie wytwarzania, importu, nabycia wewnątrzwspólnotowego paliw ciekłych lub biopaliw ciekłych, którzy sprzedają lub zbywają je w innej formie na terytorium RP lub zużywają na potrzeby własne. Aktualne poziomy NCW znajdują się w art. 7 Ustawy z dnia 30 listopada 2016 r. o zmianie ustawy - Prawo energetyczne oraz niektórych innych ustaw (Dz.U. z 2016 r. poz. 1986). Obecnie poziom NCW ustalono na $8,00 \% \mathrm{w}$ roku $2019 \mathrm{r}$. oraz $8,50 \%$ na $2020 \mathrm{r}$.
Kolejną ważną kwestią uregulowaną w ustawie (Dz.U. z 2016 r., poz. 1986) jest wprowadzenie zmian wynikających z wdrożenia dyrektywy 2015/1513, tzw. dyrektywy ILUC (Dyrektywa 2015/1513). Jedną z nich jest możliwość podwójnego naliczania biokomponentów do realizacji Narodowego Celu Wskaźnikowego (NCW). Surowce, które mogą być za takie uznane, wymienione są w załączniku nr 1 do ustawy oraz w załączniku IX (cz. A i B) do dyrektywy ILUC. Załącznik IX składa się z części A oraz B.

\section{Analiza teoretyczna}

Biometan produkuje się w wyniku oczyszczania biogazu otrzymanego metodą fermentacji. Każda $\mathrm{z}$ instalacji do produkcji biogazu ma odmienną, indywidualną konstrukcję, dostosowaną do różnego składu materiału wsadowego. Wybór wyposażenia procesowo-technicznego do danej instalacji zależy przede wszystkim od stosowanych surowców. Ilość substratów używanych do produkcji decyduje o rozmiarze wszystkich agregatów i objętości zbiorników. Jakość substratów (zawartość suchej masy, struktura, pochodzenie itd.) określa rozplanowanie techniki procesowej. Lista typowych urządzeń znajdujących się na wyposażeniu instalacji biogazowniczej zawiera (Czyrnek-Delêtre et al., 2017): zbiorniki magazynujące, komorę fermentacyjną, instalację wodno-kanalizacyjną, system ogrzewania, instalację gazową, instalację elektroenergetyczną, wyposażenie pomieszczeń i biura oraz aparaturę kontrolno-pomiarową.

Biogaz powstaje w wyniku przetworzenia biomasy, która stanowi jedno z podstawowych odnawialnych źródeł energii. Pod względem chemicznym składa się głównie z metanu i ditlenku węgla, aczkolwiek jego skład determinuje rodzaj surowców, z których został wyprodukowany. Biogaz w zależności od sposobu jego wytworzenia może być określany np. jako składowiskowy (uzyskiwany w wyniku fermentacji odpadów na składowiskach), jako biogaz z osadów ściekowych (wytwarzany w wyniku beztlenowej fermentacji szlamu kanalizacyjnego), a także biogaz rolniczy z procesu fermentacji biomasy z upraw energetycznych, pozostałości z produkcji roślinnej, odchodów zwierzęcych, odpadów z rzeźni, pozostałości po produkcji piwa itp. (Curkowski et al., 2009). Biogaz powstaje w procesie fermentacji metanowej (Kwaśny et al., 2012). Jest to proces beztlenowy, który obejmuje cztery etapy:

1) hydrolizę;

2) kwasogenezę;

3) octanogenezę;

4) metanogenezę.

W pierwszym etapie przy udziale enzymów zachodzi rozkład hydrofobowych związków organicznych, tj. białek, tłuszczów 
i węglowodanów. W wyniku tych procesów powstają aminokwasy, cukry proste, alkohole wielowodorotlenowe i kwasy thuszczowe. W kwasogenezie powstają lotne kwasy tłuszczowe, alkohol metylowy i etanol, aldehydy, octany oraz dwutlenek węgla i wodór. W metanogenezie bakterie metanowe przetwarzają powstałe kwasy karboksylowe (mrówkowy, octowy) oraz metanol, $\mathrm{CO}_{2}$ i wodór. Natomiast etanol i lotne kwasy thuszczowe W następnym etapie - octanogenezie - przetwarzane są do ditlenku węgla i wodoru za sprawą bakterii acetogennych. Ich aktywność ma wpływ na kolejny etap procesu - metanogenezę. W wyniku zahamowania wzrostu tych mikroorganizmów dochodzi do kumulacji lotnych kwasów tłuszczowych, co z kolei prowadzi do spowolnienia lub zatrzymania wzrostu bakterii metanowych. Odpowiedzialne są one za generowanie metanu z octanów lub alkoholi, a także z $\mathrm{CO}_{2}$ w wyniku jego redukcji wodorem (Głodek, 2007; Baidoo et al., 2011). Przebieg fermentacji metanowej zależy od wielu czynników - m.in. temperatury, odczynu surowca poddanego fermentacji, składu pierwiastkowego (stosunku C/N) oraz od mieszania. Ponieważ bakterie metanowe są bardziej wrażliwe na zmiany temperatury i odczynu pH niż bakterie acetogenne, proces fermentacji jest prowadzony w warunkach dogodniejszych do ich rozwoju i aktywności (Ledakowicz i Krzystek, 2005; Baidoo et al., 2011).

Do produkcji biogazu wykorzystuje się obecnie szereg surowców, zarówno odpadowych, jak i celowo wytwarzanych, pochodzących z rolnictwa, przemysłu czy z obszarów miejskich. Do najpopularniejszych surowców można zaliczyć: odpady pochodzące z produkcji spożywczej (wytłoki, wywar gorzelniany, wysłodziny browarniane, odpady tłuszczowe i nabiałowe), płynne lub stałe odchody zwierzęce (gnojowica, obornik), osady ściekowe, organiczne odpady komunalne, resztki jedzenia, odpady poubojowe, odpady z produkcji roślinnej, celowe uprawy energetyczne (kukurydza, lucerna, trawy łąkowe) oraz biomasę leśną (Głaszka, 2010). Surowce te cechuje różna wyjściowa zawartość suchej masy organicznej, szybkość rozkładu. Przekłada się to na różnice w wydajności powstającego biogazu.

\section{Część doświadczalna}

W niniejszym artykule przedstawiono wyniki kalkulacji emisji GHG w cyklu życia dla dwóch różnych ścieżek produkcji biometanu, zakładając dla każdej z nich wariant otwartego lub zamkniętego zasobnika na poferment. W związku z tym przeanalizowano następujące ścieżki:

- wariant 1: biometan otrzymywany z kukurydzy - otwarty zbiornik na poferment;

- wariant 2: biometan otrzymywany z kukurydzy - zamknięty zbiornik na poferment;

- wariant 3: biometan otrzymywany z obornika - otwarty zbiornik na poferment;

- wariant 4: biometan otrzymywany z obornika - zamknięty zbiornik na poferment.

Wybór ścieżek produkcji do porównania wynikał z faktu, że warianty poddane analizie znacznie się od siebie różnią. W przypadku kukurydzy zachodzi konieczność uwzględnienia emisji GHG związanej z pozyskaniem (uprawą) tego surowca. Wynika to z faktu, że jest to surowiec pełnowartościowy. W drugim przypadku, ze względu na odpadowy charakter surowca, emisję z pozyskania obornika na podstawie dyrektywy 2009/28/WE (Dyrektywa 2009/28/WE) uznaje się za zerową do miejsca jego zbiórki. Dodatkowo dla obu surowców wykonano porównanie dwóch różnych wariantów postępowania z wyprodukowanym pofermentem. Zakładają one przechowywania pofermentu w otwartym lub zamkniętym zbiorniku.

Dane wykorzystane w obliczeniach emisji zaczerpnięto z publikacji Buratti et al. (2013).

Emisję w cyklu życia wyznaczono na podstawie wzoru podanego w dyrektywie 2009/28/WE w załączniku V (Dyrektywa 2009/28/WE). Do obliczeń emisji GHG przyjęto szereg założeń i wykluczeń. Poszczególne składowe wzoru oraz założenia i wykluczenia odnośnie do tych składowych przedstawiono poniżej:

Eec - analizie poddano surowce pełnowartościowe oraz te o statusie odpadu lub pozostałości, w związku z tym

Tabela 1. Dane bilansowe użyte do obliczeń

Table 1. Balance sheet data used for calculations

\begin{tabular}{|c|c|c|c|c|}
\hline $\begin{array}{l}\text { Rodzaj wariantu } \\
\text { (ścieżki produkcji) }\end{array}$ & Wariant 1 & Wariant 2 & Wariant 3 & Wariant 4 \\
\hline Surowiec & \multicolumn{2}{|c|}{ kukurydza } & \multicolumn{2}{|c|}{ obornik } \\
\hline Rodzaj zbiornika na poferment & otwarty & zamknięty & otwarty & zamknięty \\
\hline Ilość surowca (sucha masa) $[\mathrm{kg}]$ & 1000 & 1000 & 1000 & 1000 \\
\hline Produkcja biogazu $\left[\mathrm{MJ}_{\text {biogaz }} / \mathrm{t}_{\text {surowca }}\right]$ & 3922 & 3922 & 432 & 432 \\
\hline Zużycie energii do produkcji (sieć zewnętrzna) [MJ] & 196,1 & 196,1 & 21,6 & 21,6 \\
\hline Zużycie energii - oczyszczanie biogazu [MJ] & 39,22 & 39,22 & 4,32 & 4,32 \\
\hline Zużycie energii - zatłaczanie biometanu do sieci gazu ziemnego [MJ] & 39,22 & 39,22 & 4,32 & 4,32 \\
\hline
\end{tabular}


Tabela 2. Stałe oraz wskaźniki niezbędne do przeprowadzenia obliczeń

Table 2. Constants and factors necessary to perform calculations

\begin{tabular}{|l|c|c|c|}
\hline \multicolumn{1}{|c|}{ Parametr } & Jednostka & Wartość & Źródlo/Uwagi \\
\hline \hline Emisja z uprawy kukurydzy & {$\left[\mathrm{g} \mathrm{CO}_{2 \mathrm{eq}} / \mathrm{kg}\right]$} & 280 & $\begin{array}{c}\text { Wartość emisji NUTS 2 przyjęta dla } \\
\text { woj. małopolskiego (Komisja } \\
\text { Europejska. Raport) }\end{array}$ \\
\hline Wydajność procesu oczyszczania (wszystkie procesy) & {$\left[\mathrm{MJ}_{\text {biometan }} / \mathrm{MJ}_{\text {biogaz }}\right]$} & 0,99 & (Buratti et al., 2013) \\
\hline Wartość opałowa biometanu & {$[\mathrm{MJ} / \mathrm{kg}]$} & 50 & Biograce II (Biograce) \\
\hline Wartość opałowa obornika (sucha masa) & {$[\mathrm{MJ} / \mathrm{kg}]$} & 12,0 & Biograce II (Biograce) \\
\hline Wartość opałowa kukurydzy & {$[\mathrm{MJ} / \mathrm{kg}]$} & 16,9 & Biograce II (Biograce) \\
\hline Dodatkowa emisja - otwarty zbiornik na poferment (kukurydza) & {$\left[\mathrm{g} \mathrm{CO}_{2 \mathrm{eq}} / \mathrm{MJ}_{\text {biogaz }}\right]$} & 13,51 & Biograce II (Biograce) \\
\hline Dodatkowa emisja - otwarty zbiornik na poferment (obornik) & {$\left[\mathrm{g} \mathrm{CO}_{2 \mathrm{eq}} / \mathrm{MJ}_{\text {biogaz }}\right]$} & 69,56 & Biograce II (Biograce) \\
\hline Ograniczenie emisji GHG poprzez wykorzystanie obornika & {$\left[\mathrm{g} \mathrm{CO}_{2 \mathrm{eq}} / \mathrm{MJ}_{\text {biogaz }}\right]$} & $-45,05$ & Biograce II (Biograce) \\
\hline Wskaźnik emisji GHG energii elektrycznej & {$\left[\mathrm{g} \mathrm{CO}_{2 \mathrm{eq}} / \mathrm{MJ}\right]$} & 129,19 & Biograce 4d (Biograce) \\
\hline
\end{tabular}

wartość składowej dla obornika wynosi zero, natomiast dla kukurydzy przyjęto wartość emisji z uprawy na poziomie NUTS 2 dla województwa małopolskiego;

El - w przypadku analizowanych surowców wartość składowej wynosi zero;

Ep - składowe liczone w dalszej części pracy;

Etd - zakłada się przerób w tym samym miejscu co punkt zbiórki surowca, uwzględniono tylko składową związaną z dystrybucją (wartość $0,55 \mathrm{~g} \mathrm{CO}_{2 \mathrm{eq}} / \mathrm{MJ}$ ) (System KZR INiG);

$\mathrm{Eu}$ - dla paliw z biomasy wartość wynosi zero;

Esca - składowa równa zero (brak ograniczenia) - technika niestosowana;

Eccs - składowa równa zero (brak ograniczenia) - technika niestosowana;

Eccr - składowa równa zero (brak ograniczenia) - technika niestosowana;

Eee - składowa równa zero (brak ograniczenia) - technika niestosowana.

Dodatkowo (i) pominięto emisję związaną z zastosowaniem katalizatorów do procesu, (ii) pominięto emisję związaną z zastosowaniem enzymów, (iii) nie uwzględniono emisji związanej z produkcją maszyn i urządzeń, (iv) założono, że instalacje są podłączone do zewnętrznej sieci elektrycznej, oraz $(v)$ zgodnie z dyrektywą (Dyrektywa 2009/28/WE) ditlenek węgla powstający w procesie fermentacji ze względu na biologiczne pochodzenie nie został wzięty pod uwagę w kalkulacjach.

\section{Obliczenie wielkości emisji gazów cieplarnianych (GHG)}

Obliczenia emisji GHG wykonano zgodnie z metodyką KZR INiG (System KZR INiG) na podstawie danych zawartych w tabelach 1 i 2, opierając się na przyjętych założeniach.
1) Wyznaczenie współczynników surowcowych

Współczynnik surowcowy kukurydza/biogaz $\left(\mathrm{FF}_{\text {bioga }}\right)$ :

$\mathrm{FF}_{\text {biogaz }}=$ ilość MJ kukurydzy / ilość MJ biogazu

$\mathrm{FF}_{\text {biogaz }}=(16,9 \mathrm{MJ} / \mathrm{kg} \times 1000 \mathrm{~kg}) / 3922 \mathrm{MJ}=$

$$
4,31 \mathrm{MJ}_{\text {kukurydza }} / \mathrm{MJ}_{\text {biogaz }}
$$

Współczynnik surowcowy obornik/biogaz $\left(\mathrm{FF}_{\text {biogaz }}\right)$ :

$\mathrm{FF}_{\text {biogaz }}=$ ilość MJ obornika / ilość MJ biogazu

$\mathrm{FF}_{\text {biogaz }}=(12,0 \mathrm{MJ} / \mathrm{kg} \times 1000 \mathrm{~kg}) / 432 \mathrm{MJ}=$

$$
27,78 \mathrm{MJ}_{\text {obornik }} / \mathrm{MJ}_{\text {biogaz }}
$$

Współczynnik surowcowy dla procesu oczyszczania bioga$\mathrm{zu}$ - biometan/biogaz (wszystkie instalacje):

$$
\begin{gathered}
\mathrm{FF}_{\text {biometan }}=1 \mathrm{MJ} \text { biogazu } / 0,99 \mathrm{MJ} \text { biometanu }= \\
1,01 \mathrm{MJ}_{\text {biogaz }} / \mathrm{MJ}_{\text {biometan }}
\end{gathered}
$$

2) Wyznaczenie współczynników alokacji

Ze względu na to, że w procesach powstaje tylko jeden produkt (biogaz), do którego przydzielana jest całość emisji GHG, natomiast do pofermentu nie przydziela się emisji (produkt o charakterze pozostałości), współczynnik alokacji wynosi $1 \mathrm{w}$ każdym analizowanym przypadku.

3) Przeliczenie emisji GHG z uprawy kukurydzy na $1 \mathrm{MJ}$ biometanu

Kukurydza, jako surowiec pełnowartościowy, wnosi z sobą składową emisji związaną z jej uprawą. Wartość ta wyznaczona jest w przeliczeniu na $1 \mathrm{~kg}$ kukurydzy. Przeliczenia tej wielkości na $1 \mathrm{MJ}$ biometanu dokonano w sposób podany poniżej:

Eec kukurydzy $=\left(280 \mathrm{~g} \mathrm{CO}_{2 \mathrm{eq}} / \mathrm{kg} \times 4,31 \mathrm{MJ} / \mathrm{MJ} \times\right.$ $\left.1,01 \mathrm{MJ}_{\text {biogaz }} / \mathrm{MJ}_{\text {biometan }}\right) / 16,9 \mathrm{MJ} / \mathrm{kg}=72,12 \mathrm{~g} \mathrm{CO}_{2 \mathrm{eq}} / \mathrm{MJ}$

4) Oszacowanie emisji GHG z procesów technologicznych

Emisję z produkcji wyznaczono na podstawie zużycia energii elektrycznej w poszczególnych procesach.

\section{- Biometan z kukurydzy}

Emisja z produkcji biogazu:

$$
\begin{gathered}
\mathrm{E}_{\mathrm{p} 1}=\left(196,1 \mathrm{MJ}_{\text {en.elektr }} \times 1,01 \mathrm{MJ}_{\text {biogaz }} / \mathrm{MJ}_{\text {biometan }} \times 129,19 \mathrm{~g}\right. \\
\left.\mathrm{CO}_{2 \mathrm{eq}} / \mathrm{MJ}\right) / 3922 \mathrm{MJ}_{\text {biogaz }}=6,52 \mathrm{~g} \mathrm{CO}_{2 \mathrm{eq}} / \mathrm{MJ}_{\text {biometan }}
\end{gathered}
$$


Emisja z wykorzystania energii użytej do oczyszczenia biogazu:

$\mathrm{E}_{\mathrm{p} 2}=\left(39,22 \mathrm{MJ}_{\text {en.elektr }} / \mathrm{MJ}_{\text {biometan }} \times 129,19 \mathrm{~g} \mathrm{CO}_{2 \mathrm{eq}} / \mathrm{MJ} \times 1,01\right.$

Emisja z wykorzystania energii użytej do zatłaczania biometanu do sieci gazu ziemnego:

$\mathrm{E}_{\mathrm{p} 3}=\left(39,22 \mathrm{MJ}_{\text {en. elektr }} / \mathrm{MJ}_{\text {biometan }} \times 129,19 \mathrm{~g} \mathrm{CO}_{2 \mathrm{eq}} / \mathrm{MJ} \times 1,01\right.$

$\left.\mathrm{MJ}_{\text {biogaz }} / \mathrm{MJ}_{\text {biometan }}\right) / 3922 \mathrm{MJ}_{\text {biogaz }}=1,30 \mathrm{~g} \mathrm{CO}_{2 \mathrm{eq}} / \mathrm{MJ}_{\text {biometan }}$

Całkowita emisja z procesu technologicznego: $\mathrm{E}_{\mathrm{p}}=\mathrm{E}_{\mathrm{p} 1}+\mathrm{E}_{\mathrm{p} 2}+\mathrm{E}_{\mathrm{p} 3}$

$$
\begin{gathered}
\mathrm{E}_{\mathrm{p}}=6,52 \mathrm{~g} \mathrm{CO}_{2 \mathrm{eq}} / \mathrm{MJ}_{\text {biometan }}+1,30 \mathrm{~g} \mathrm{CO}_{2 \mathrm{eq}} / \mathrm{MJ}_{\text {biometan }}+ \\
\quad 1,30 \mathrm{~g} \mathrm{CO}_{2 \mathrm{eq}} / \mathrm{MJ}_{\text {biometan }}=9,12 \mathrm{~g} \mathrm{CO}_{2 \mathrm{eq}} / \mathrm{MJ}_{\text {biometan }}
\end{gathered}
$$

Dodatkowo dla wariantu otwartego zbiornika z pofermentem należy uwzględnić emisję (wartość stała na podstawie Biograce II (Biograce)) na poziomie 13,51 g CO $\mathrm{Ceq}_{2 \mathrm{MJ}} / \mathrm{MJ}_{\text {biogaz }}$, czyli w przeliczeniu na $1 \mathrm{MJ}$ biometanu:

$$
\begin{gathered}
13,51 \mathrm{~g} \mathrm{CO}_{2 \mathrm{eq}} / \mathrm{MJ}_{\text {biogaz }} \times 1,01 \mathrm{MJ}_{\text {biogaz }} / \mathrm{MJ}_{\text {biometan }}= \\
13,64 \mathrm{~g} \mathrm{CO}_{2 \mathrm{eq}} / \mathrm{MJ}_{\text {biometan }}
\end{gathered}
$$

\section{- Biometan z obornika}

Emisja z produkcji biogazu:

$$
\mathrm{E}_{\mathrm{p} 1}=\left(21,6 \mathrm{MJ}_{\text {en.lekktr }} \times 1,01 \mathrm{MJ}_{\text {biogaz }} / \mathrm{MJ}_{\text {biometan }} \times\right.
$$

$\left.129,19 \mathrm{~g} \mathrm{CO}_{2 \mathrm{eq}} / \mathrm{MJ}\right) / 432 \mathrm{MJ}_{\text {biogaz }}=6,52 \mathrm{~g} \mathrm{CO}_{2 \mathrm{eq}} / \mathrm{MJ}_{\text {biometan }}$

Emisja z wykorzystania energii użytej do oczyszczenia biogazu:

$\mathrm{E}_{\mathrm{p} 2}=\left(4,32 \mathrm{MJ}_{\text {en.elektr }} / \mathrm{MJ}_{\text {biometan }} \times 129,19 \mathrm{~g} \mathrm{CO}_{2 \mathrm{eq}} / \mathrm{MJ} \times 1,01\right.$

$\left.\mathrm{MJ}_{\text {biogaz }} / \mathrm{MJ}_{\text {biometan }}\right) / 432 \mathrm{MJ}_{\text {biogaz }}=1,30 \mathrm{~g} \mathrm{CO}_{\text {2eq }} / \mathrm{MJ}_{\text {biometan }}$

Emisja z wykorzystania energii użytej do zatłaczania biometanu do sieci gazu ziemnego:

$$
\mathrm{E}_{\mathrm{p} 3}=\left(4,32 \mathrm{MJ}_{\text {en.lelekr }} / \mathrm{MJ}_{\text {biometan }} \times 129,19 \mathrm{~g} \mathrm{CO}_{2 \mathrm{eq}} / \mathrm{MJ} \times 1,01\right.
$$$$
\left.\mathrm{MJ}_{\text {biogaz }} / \mathrm{MJ}_{\text {biometan }}\right) / 432 \mathrm{MJ}_{\text {biogaz }}=1,30 \mathrm{~g} \mathrm{CO}_{2 e q} / \mathrm{MJ}_{\text {biometan }}
$$

Całkowita emisja z procesu technologicznego:

$\mathrm{E}_{\mathrm{p}}=\mathrm{E}_{\mathrm{p} 1}+\mathrm{E}_{\mathrm{p} 2}+\mathrm{E}_{\mathrm{p} 3}$

$$
\begin{gathered}
\mathrm{E}_{\mathrm{p}}=6,52 \mathrm{~g} \mathrm{CO}_{2 \mathrm{eq}} / \mathrm{MJ}_{\text {biometan }}+1,30 \mathrm{~g} \mathrm{CO}_{2 \mathrm{eq}} / \\
\mathrm{MJ}_{\text {biometan }}+1,30 \mathrm{~g} \mathrm{CO}_{2 \mathrm{eq}} / \mathrm{MJ}_{\text {biometan }}= \\
\text { 9,12 } \mathrm{g} \mathrm{CO}_{2 \mathrm{eq}} / \mathrm{MJ}_{\text {biometan }} \\
\text { Dodatkowo dla przypadku otwartego zbior- }
\end{gathered}
$$
nika z pofermentem należy uwzględnić emisję (wartość stała na podstawie Biograce II (Biograce)) na poziomie 69,56 $\mathrm{g} \mathrm{CO}_{2 \mathrm{eq}} / \mathrm{MJ}_{\text {biogaz }}$, czyli w przeliczeniu na $1 \mathrm{MJ}$ biometanu: $69,56 \mathrm{~g} \mathrm{CO}_{2 \mathrm{eq}} / \mathrm{MJ}_{\text {biogaz }} \times 1,01 \mathrm{MJ}_{\text {biogaz }} / \mathrm{MJ}_{\text {biometan }}$ $=70,25 \mathrm{~g} \mathrm{CO}_{2 \mathrm{eq}} / \mathrm{MJ}_{\text {biometan }}$

W związku z zastosowaniem obornika przydzielone jest ograniczenie emisji GHG na poziomie $-45,05 \mathrm{~g} \mathrm{CO}_{2 \mathrm{eq}} / \mathrm{MJ}_{\text {biogaz }}$ (Biograce), czyli w przeliczeniu na $1 \mathrm{MJ}$ biometanu:

$$
\begin{gathered}
-45,05 \mathrm{~g} \mathrm{CO}_{2 \mathrm{eq}} / \mathrm{MJ}_{\text {biogaz }} \times 1,01 \mathrm{MJ}_{\text {biogaza }} / \\
\mathrm{MJ}_{\text {biometan }}=-45,50 \mathrm{~g} \mathrm{CO}_{2 \mathrm{eq}} / \mathrm{MJ}_{\text {biometan }}
\end{gathered}
$$

4) Emisja $z$ transportu i dystrybucji

Zgodnie z założeniami surowce były przetwarzane w miejscu zbiórki, zatem brak jest dodatkowej emisji z transportu. Uwzględniono natomiast emisję związaną z dystrybucją. Ze względu na to, że emisja ta jest generowana na etapie późniejszym, który nie był objęty analizą, możliwe jest w takim przypadku użycie wartości emisji na poziomie $0,55 \mathrm{~g} \mathrm{CO}_{2} / \mathrm{MJ}$ finalnego paliwa (System $\mathrm{KZR} \mathrm{INiG}$ ), na które składają się emisje wygenerowane (i) przez bazę paliwową: $0,11 \mathrm{~g} \mathrm{CO}_{2} / \mathrm{MJ}$ paliwa (na podstawie zużycia energii elektrycznej w ilości 0,00084 MJ/MJ paliwa i wartości standardowych dla energii elektrycznej NG CCGT oraz energii elektrycznej UE NN Mix) oraz (ii) stację paliw: 0,44 $\mathrm{g} \mathrm{CO}_{2} / \mathrm{MJ}$ paliwa (na podstawie zużycia energii elektrycznej $0,0034 \mathrm{MJ} / \mathrm{MJ}$ paliwa i standardowej wartości dla energii elektrycznej w UE NN Mix).

5) Całkowita emisja GHG

W tabeli 3 przedstawiono oszacowane emisje GHG dla poszczególnych analizowanych procesów.

6) Wyznaczenie ograniczenia emisji GHG względem odpowiednika kopalnego

Na podstawie otrzymanych wyników wyznaczono ograniczenie emisji GHG względem odpowiednika kopalnego

\begin{tabular}{|c|c|c|c|c|c|}
\hline & odzaj wariantu & Wariant 1 & Wariant 2 & Wariant 3 & Wariant 4 \\
\hline Suro & & kuk & ydza & obc & nik \\
\hline Rod & biornika na poferment & otwarty & zamknięty & otwarty & zamknięty \\
\hline Skła & a emisji GHG & & {$\left[\mathrm{g} \mathrm{CO}_{2 \mathrm{eq}} / \mathrm{M}\right.$} & biometanu] & \\
\hline Eec & & 72,12 & 72,12 & 0 & 0 \\
\hline El & & 0 & 0 & 0 & 0 \\
\hline Ep & $\begin{array}{l}\text { fermentacja } \\
\text { oczyszczanie } \\
\text { zatłaczanie }\end{array}$ & 9,12 & 9,12 & 9,12 & 9,12 \\
\hline & $\begin{array}{l}\text { dodatkowa emisja - } \\
\text { zasobnik otwarty }\end{array}$ & 13,64 & 0 & 70,25 & 0 \\
\hline Etd & & 0,55 & 0,55 & 0,55 & 0,55 \\
\hline $\begin{array}{l}\text { Esca } \\
\text { obor }\end{array}$ & emia - zastosowanie & 0 & 0 & $-45,50$ & $-45,50$ \\
\hline Eccr & & 0 & 0 & 0 & 0 \\
\hline Eccs & & 0 & 0 & 0 & 0 \\
\hline Eee & & 0 & 0 & 0 & 0 \\
\hline & SUMA & 95,43 & 81,79 & 35,32 & $-35,83$ \\
\hline
\end{tabular}
(Dyrektywa 2009/28/WE) według wzoru:

$$
\text { OGRANICZENIE }=\left(E_{F}-E_{B}\right) / E_{F}
$$

gdzie:

$E_{B}$ - całkowita emisja wyznaczona dla poszczególnych ścieżek produkcji biometanu,

$E_{F}$ - całkowita emisja z kopalnego odpowiednika biopaliwa, wynosząca 83,8 g CO $2 \mathrm{eq} / \mathrm{MJ}$.

W tabeli 4 przedstawiono wyliczone emisje GHG z poszczególnych analizowanych procesów.

Tabela 3. Wyznaczone składowe emisji GHG dla biometanu

Table 3. Calculated components of GHG emissions of biomethane 
Tabela 4. Wyznaczone poziomy ograniczenia emisji GHG względem odpowiednika kopalnego

Table 4. Calculated GHG emission savings compared to the fossil equivalent

\begin{tabular}{|l|c|c|c|c|}
\hline \multicolumn{1}{|c|}{ Rodzaj wariantu } & Wariant 1 & Wariant 2 & Wariant 3 & Wariant 4 \\
\hline Surowiec & \multicolumn{2}{|c|}{ kukurydza } & \multicolumn{2}{c|}{ obornik } \\
\hline Rodzaj zbiornika na poferment & otwarty & zamknięty & otwarty & zamknięty \\
\hline Ograniczenie emisji GHG [\%] & -14 & 2 & 59 & 143 \\
\hline
\end{tabular}

\section{Podsumowanie}

W ramach badań, których wyniki przedstawiono w niniejszej pracy, przeanalizowano proces produkcji biogazu w celu uzyskania biometanu, traktując jednocześnie biometan jako biopaliwo. Biometan uzyskuje się w wyniku oczyszczania biogazu wyprodukowanego w biogazowni, a następnie poprzez sprężanie można włączyć ten strumień do sieci gazu ziemnego. Istnieje wiele surowców, z których można otrzymać biogaz, począwszy od surowców rolniczych pełnowartościowych poprzez pozostałości z procesów przetwórczych aż po odpady rolnicze, m.in. obornik. Jednak zgodnie z obecnymi przepisami każde biopaliwo może być zaliczone na poczet realizacji Narodowego Celu Wskaźnikowego dopiero po spełnieniu tzw. kryteriów zrównoważonego rozwoju. Jednym z nich jest minimalny poziom ograniczenia emisji gazów cieplarnianych liczony w cyklu życia. Obecne wymogi ograniczenia emisji są zależne od wieku instalacji produkcyjnej i wynoszą 50\% lub 60\% w zależności od wieku instalacji, na której wytworzono biopaliwo.

W ramach badań przeanalizowano dwie ścieżki produkcji biometanu, przy czym każdą z nich w dwóch wariantach. Pierwsza ścieżka dotyczyła produkcji biometanu z wykorzystaniem kukurydzy jako surowca. Ścieżkę tę rozpatrywano w dwóch wariantach, tj. $\mathrm{z}$ otwartym lub zamkniętym zbiornikiem na poferment. Druga ścieżka zakładała produkcję biometanu z obornika, również w dwóch wariantach postępowania $z$ otrzymanym pofermentem. Obliczenia prowadzono na podstawie dostępnych danych bilansowych biogazowni przy zastosowaniu metodyki KZR INiG, opartej na wytycznych zawartych w dyrektywie 2009/28/WE. Pozyskane dane oraz wyniki obliczeń dla obu wariantów surowcowych pokazały, że emisja wygenerowana przez instalację (jej źródłem było zużycie energii elektrycznej) nie różniła się znacząco i w każdym z wariantów odegrała drugorzędny wpływ na wynik. Największe znaczenie miały różnice wynikające $\mathrm{z}$ wyboru surowca oraz sposobu postępowania z wytworzoną pozostałością po procesie fermentacji. W przypadku pełnowartościowej kukurydzy konieczne jest uwzględnienie emisji z etapu jej uprawy. Składowa emisji z uprawy kukurydzy, po jej przeliczeniu zgodnie z metodyką na wartość odnoszącą się do $1 \mathrm{MJ}$ wyprodukowanego biometanu, jest na tyle wysoka, że produkcja nastawiona na rynek biopaliwowy nie spełnia kryteriów zrównoważonego rozwoju w zakresie emisji GHG. Wyeliminowanie składowej emisji z pozyskania surowca umożliwia wykorzystywanie surowców o statusie odpadów lub pozostałości. Wówczas emisja z ich pozyskania aż do miejsca ich zbiórki jest równa zero. Dlatego w ramach niniejszej pracy przeanalizowano pod kątem emisyjności proces z użyciem obornika. W związku z odpadowym charakterem surowca emisja z pozyskania obornika jest zerowa, co na starcie pozwoliło uniknąć istotnej składowej emisji GHG. Dodatkowym atutem tego surowca jest możliwość zastosowania premii w postaci składowej ujemnej. Dzięki zerowej emisji wnoszonej z surowcem oraz możliwości zastosowania premii biometan otrzymany z obornika spełnił kryteria zrównoważonego rozwoju w zakresie emisji GHG nawet dla instalacji z otwartym zbiornikiem na poferment $(59 \%$ przy wymaganych $50 \%$ dla instalacji uruchomionych przed 5 października 2015 r.). Gromadzenie pofermentu w zamkniętych zbiornikach przy jednoczesnym uwzględnieniu premii za użycie obornika pozwoliło uzyskać ograniczenie emisji GHG powyżej $100 \%$. W związku z tym producenci biogazu nastawieni na wytwarzanie biometanu do celów transportowych powinni wybierać takie surowce, które generują jak najniższą emisję ze swego pozyskania, a najlepiej takie, które nie wnoszą jej wcale. Zamknięte zbiorniki na poferment eliminują z kolei emisję metanu, która bardzo niekorzystnie wpływa na ostateczny wynik obliczeń. Emisje te nie są opomiarowane, w związku z tym wskaźniki, jakie należy stosować ze względu na ich wielkość, znacznie podnoszą sumaryczną emisję. Wielkość przyjmowanego wskaźnika zależy od rodzaju użytego surowca, jednak w obu analizowanych przypadkach miał on duży wpływ na obliczenia. W przypadku kukurydzy była to druga co do wielkości składowa emisji, natomiast w przypadku obornika była to najwyższa spośród wszystkich składowych.

Biometan, o emisji na poziomie dopuszczonym przez wymagania dyrektywy 2009/28/WE, może być użyty jako biopaliwo silnikowe. Innym sposobem wykorzystania biometanu w produkcji paliw transportowych może być zastosowanie go jako surowca do dalszego przetwarzania. Takim przykładem może być wytwarzanie wodoru poprzez reforming parowy biometanu. Ten z kolei jest powszechnie wykorzystywany do wodorowych procesów rafineryjnych, w wyniku czego 
część użytego wodoru jest wbudowywana w cząsteczki komponentów paliw silnikowych. W przypadku dalszego przetwarzania biometanu do innych biopaliw generowana jest dodatkowa emisja GHG w cyklu życia, którą również należy uwzględniać w kalkulacjach. Tym samym wskaźnik emisji dla finalnego biopaliwa ulegnie pogorszeniu (wzrost wartości). W związ$\mathrm{ku}$ z tym producenci biopaliw zainteresowani przetwarzaniem biometanu muszą pozyskać surowiec o takiej wartości emisji, która po dodaniu własnych emisji (z przetwarzania, transportu) w dalszym ciągu pozwoli spełnić kryterium minimalnego ograniczenia emisji GHG. Zatem producenci biogazu, którzy zamierzają uczestniczyć w łańcuchu dostaw biopaliw silnikowych, niezależnie od sposobu finalnego wykorzystania (jako samoistne paliwo lub surowiec do dalszego przetwarzania), powinni zwrócić szczególną uwagę na kwestię emisyjności, w przypadku której, jak pokazano, największy wpływ na wynik mają dobór surowca oraz rodzaj instalacji.

Artykuł powstał na podstawie pracy statutowej pt. Ocena wptywu kluczowych czynników na emisję GHG w cyklu życia biometanu (LCA) - praca INiG - PIB na zlecenie MNiSW; nr zlecenia 0024/TP/2019, nr archiwalny DK-4100-0016/2019.

\section{Literatura}

Adams P.W.R., McManus M., 2019. Characterisation and variability of greenhouse gas emissions from biomethane production via anaerobic digestion of maize. Journal of Cleaner Production, 218: 529-542.

Adelt M., Wolf D., Vogel A., 2011. LCA of biomethane. Journal of Natural Gas Science and Engineering, 3: 646-650.

Ardolino F., 2018. Biowaste-to-biomethane or biowaste-to-energy? An LCA study on anaerobic digestion of organic waste. Journal of Cleaner Production, 174: 462-476.

Baidoo M., Arthur R., Antwi E., 2011. Biogas as a potential renewable energy source: A Ghanaian case study. Renewable Energy, 36: $1510-1516$.

Buratti C., Barbanera M., Fantozzi F., 2013. Assessment of GHG emissions of biomethane from energy cereal crops in Umbria, Italy. Applied Energy, 108: 128-136.

Curkowski A., Mroczkowski P., Oniszk-Popławska A., Wiśniewski G., 2009. Biogaz rolniczy - produkcja i wykorzystanie. Mazowiecka Agencja Energetyczna Sp. z o.o., Warszawa.

Czyrnek-Delêtre M., Rocca S., Agostini A., Giuntoli J., Murphy J.D., 2017. Life cycle assessment of seaweed biomethane, generated from seaweed sourced from integrated multi-trophic aquaculture in temperate oceanic climates. Applied Energy, 196: 34-50.

Esteves E., Naranjo Herrera A.M., Esteves V., Morgado C., 2019. Life cycle assessment of manure biogas production: A review. Journal of Cleaner Production, 5: 411-423. DOI: 10.1016/j. jclepro.2019.02.091.

Głaszka A., 2010. Biogazownie rolnicze. Multico Oficyna Wydawnicza, Warszawa.

Głodek E. (red.), 2007. Pozyskiwanie i energetyczne wykorzystanie biogazu rolniczego. Wyd. Instytut Śląski, Opole.
Horschig T., Adams P.W.R., Röder M., Thornley P., Thrän D., 2016. Reasonable potential for GHG savings by anaerobic biomethane in Germany and UK derived from economic and ecological analyses. Applied Energy, 184: 840-852.

Koido K., Takeuchi H., Hasegawa T., 2018. Life cycle environmental and economic analysis of regional-scale food-waste biogas production with digestate nutrient management for fig fertilization. Journal of Cleaner Production, 190: 552-562.

Kwaśny J., Banach M., Kowalski Z., 2012. Przegląd technologii produkcji biogazu różnego pochodzenia. Czasopismo Techniczne, Politechnika Krakowska, 109: 83-102.

Ledakowicz S., Krzystek L., 2005. Wykorzystanie fermentacji metanowej w utylizacji odpadów przemysłu rolno-spożywczego. Biotechnologia, 3: 165-183.

Pulka J., 2019.Potencjał biogazu rolniczego na tle innych rodzajów OZE. Technika Rolnicza, Ogrodnicza i Leśna, 2: 15-17.

Szabó G., Fazekas I., Szabó S., Szabó G., Buday T., Paládi M., Kisari K., Kerényi A., 2014. The carbon footprint of a biogas power plant. Environmental Engineering and Management Journal, 11: 2867-2874. DOI: 10.30638/eemj.2014.322.

Szparkowska I., 2004. Wykorzystanie biogazu jako niekonwencjonalnego źródła energii na obszarze Polski. Kwartalnik Ekotechnika, 1: $1-6$

Tonini D., Hamelin L., Alvarado-Morales M., Astrup T., 2016. GHG emission factors for bioelectricity, biomethane, and bioethanol quantified for 24 biomass substrates with consequential life-cycle assessment. Bioresource Technology, 208: 123-133.

\section{Akty prawne i dokumenty normatywne}

Biograce. <https://www.biograce.net> (dostęp: październik 2019). Dyrektywa Parlamentu Europejskiego i Rady 2009/28/WE z dnia 23 kwietnia 2009 r. w sprawie promowania stosowania energii ze źródeł odnawialnych zmieniająca i w następstwie uchylająca dyrektywy 2001/77/WE oraz 2003/30/WE.

Dyrektywa Parlamentu Europejskiego i Rady (UE) 2015/1513 z dnia 9 września 2015 r. zmieniająca dyrektywę 98/70/WE odnoszącą się do jakości benzyny i olejów napędowych oraz zmieniająca dyrektywę 2009/28/WE w sprawie promowania stosowania energii ze źródeł odnawialnych.

Komisja Europejska. Raport. < https://ec.europa.eu/energy/sites/ener/ files/documents/pre-iluc_directive_nuts2_report_values_mj_kg july_2018.pdf> (dostęp październik 2019).

System KZR INiG. <http://www.kzr.inig.eu/pl/menu2/dokumenty-sytemowe/aktualne-dokumenty/> (dostep: październik 2019).

Ustawa z dnia 25 sierpnia 2006 r. o biokomponentach i biopaliwach ciekłych (Dz.U. z 2006 r. nr 169, poz. 1199).

Ustawa z dnia 30 listopada 2016 r. o zmianie ustawy - Prawo energetyczne oraz niektórych innych ustaw (Dz.U. z 2016 r. poz. 1986).

Mgr Kamil BERDECHOWSKI
Starszy specjalista badawczo-techniczny w Zakładzie
Paliw i Procesów Katalitycznych
Instytut Nafty i Gazu - Państwowy Instytut Badawczy
ul. Lubicz 25 A
31-503 Kraków
E-mail: kamil.berdechowski@inig.pl

